logos_i_ethos_2016_(40)_numer_specjalny_1, s. 29-40

DOI: http://dx.doi.org/10.15633/lie.1696

Witold Nowak

Uniwersytet Rzeszowski

\title{
Radość zbierania. Filozoficzne aspekty kolekcjonerstwa
}

Bardzo wielu spośród nas coś zbiera. Nasze zbieracze motywacje często pozostają nieprzejrzyste nie tylko dla innych - ci chętnie widzą w nich przejaw ekscentryzmu ${ }^{1}-$ lecz i dla nas samych. Zbieranie przyjmuje nieskończenie wiele odmian:

Witold M. Nowak, dr hab., pracownik Instytutu Historii Uniwersytetu Rzeszowskiego; zajmuje się filozofią kultury, antropologią filozoficzną i filozofią historii; publikacje: Spór o nowoczesność w poglądach Charlesa Taylora i Alasdaira MacIntyre'a, Rzeszów 2008. wpływa na nie ethnos i kultura, wiek, wykształcenie, doświadczenie, stan zamożności, a także płeć osoby zbierającej. Zbiera się rzeczy z jednej lub co częstsze - $\mathrm{z}$ wielu dziedzin przedmiotowych.

Warto dostrzec, że zbieractwo jest humanum i spotykamy je u ludzi od początków kultury. Kultury zbieracko-łowieckie to te, w których praktyki zbierania odgrywały podstawową rolę w podtrzymywaniu życia biologicznego $^{2}$. Z czasem zbieranie w znacznym stopniu oddzieliło się od swej roli służebnej wobec zwykłego przeżycia i przybrało odmiany nakierowane na zyskanie społecznego prestiżu, a także na spełnienie wyrafinowanych potrzeb człowieka, zwłaszcza potrzeb estetycznych.

Do tradycyjnych dziedzin przedmiotowych skupiających uwagę zbieraczy należały: biżuteria, meble, książki, kobierce i dywany, ceramika, porcelana, srebra stołowe, obrazy, sztychy i rzeźba, zegary, monety i medale.

1 E. Drüe, Ekscentryczność jako otwarty wyraz duchowości, [w:] Duch i dusza, red. P. Dybel, Warszawa 2001, s. 71-83.

2 Por. M. Sommer, Zbieranie. Próba filozoficznego ujęcia, tłum. J. Merecki, Warszawa 2003, s. 91-105. 
Spośród rzeczy wytwarzanych w niedawnych czasach dołączyły do nich: znaczki pocztowe, plakaty, pocztówka, karty telefoniczne, a także inne, niekiedy zdumiewające swą trywialnością przedmioty ${ }^{3}$. Dziś - w czasach, gdy kolekcjonowanie rzeczy stało się pasją demokratyczną - ludzie zbierają niemal wszystko lub, mówiąc dokładniej, niemal każda dziedzina przedmiotów znajduje swoich zbieraczy. To, co pozostaje - rzeczy, których nie chce nikt - są odpadami. Wszystkie inne są semioforami, czyli obiektami niosącymi znaczenie i stanowiącymi korelaty wartości ${ }^{4}$.

Zamierzam pokazać, jakich przyjemności i radości dostarcza i może dostarczać zbieranie rzeczy i tworzenie kolekcji. Będzie tu mowa o przyjemnościach zmysłowych, o afektach, które budzą w nas rzeczy, ale także o długotrwałych stanach afektywnych, czyli uczuciach, i wreszcie o bardzo wysokich satysfakcjach intelektualnych, których doznają zbieracze ${ }^{5}$.

\section{Filozofowie wobec rzeczy}

Zauważmy najpierw, że filozofowie rzadko skupiali swą uwagę na rzeczach w ich idiomatyczności, a tym samym na ich kolekcjonowaniu. Problematyka rzeczy podejmowana była wprawdzie w obszarze ontologii, ale tu każda rzecz istniejąca traktowana była z reguły jako przypadek bytu pojętego w jego ogólności. Jakościowe uposażenie rzeczy jawi się w perspektywie filozofii bytu jako drugorzędne wobec samego faktu jej istnienia - tego, że jest. O takim spojrzeniu na rzeczy w tradycji filozofii Zachodu zdecydowała właściwa starożytnej filozofii preferencja dla ujęć ogólnych, czyli dla poszukiwania w rzeczach cech gatunkowych, a nie tego, co mogłoby stanowić ich haecceitas ${ }^{6}$. Po drugie, tradycji filozoficznej, zwłaszcza

3 Zwyczajność wielu rzeczy zbieranych przez ludzi, np. magnesów na lodówkę lub opakowań po artykułach spożywczych, nie powinna przesłaniać nam faktu, że i one są semioforami, to znaczy, że niosą znaczenia i mają moc odnoszenia nas do całości kultury.

4 Pojęcie rzeczy jako semioforu rozwijał Krzysztof Pomian w swoich studiach nad historią kultury i historią kolekcjonerstwa. Por. zwłaszcza K. Pomian, Jak uprawiać historię kultury, „Przegląd Historyczny” (1995), nr 1, s. 1-13.

5 Por. D. A. Norman, Wzornictwo i emocje, tłum. D. Skalska-Stefańska, Warszawa 2015.

6 Por. S. Swieżawski, Zbieżności metafizyki realistycznej i historiografii, [w:] Szkice filozoficzne. Romanowi Ingardenowi $w$ darze, Warszawa-Kraków 1964, s. 267-287. Zasada powyż- 
starożytności i średniowiecza, właściwy był praktyczny ascetyzm. Dobra zewnętrzne, w tym cenne ze społecznego punktu widzenia przedmioty, filozofowie lekceważyli lub traktowali jedynie oglądowo, bez pasji posesywnej. Z powyższego powodu filozofowie przednowożytni nieczęsto bywali kolekcjonerami czy choćby zbieraczami. Sytuację odmienił renesans, gdy zwrócono się ku pozostałościom po antyku, wyszukiwano je i gromadzono niczym relikwie, a kolekcje dzieł sztuki oraz gabinety historii naturalnej stały się - jako że mentalność filozoficzna zbliżyła się z naukową elementami wyposażenia badawczego równie istotnymi jak biblioteki ${ }^{7}$. $\mathrm{W}$ czasach nowszych niechlubnie na polu zbierania dzieł sztuki zapisał się Wolter, który, przez wiele lat będąc posłańcem Katarzyny II (1729-1796), kupił dla carycy Rosji większość najcenniejszych dzieł francuskiej sztuki XVIII w. i wcześniejszej. Tym samym pozbawił swój kraj na rzecz Rosji ogromnej części narodowego majątku i kulturalnego dziedzictwa ${ }^{8}$.

\section{Kulturowa historia materialności}

Byłoby ze wszech miar potrzebne napisanie studium poświęconego stosunkowi poszczególnych epok do sfery materialnej. W autentycznych kulturach pierwotnych rzecz nigdy nie jest tylko rzeczą, trywialnym obiektem, którym może rozporządzać ktokolwiek. Rzecz, podobnie jak całe środowisko naturalne, nie jest neutralna. Jest natomiast tak, że rzecz ma moc, jest fetyszyzowana, a niekiedy tabuizowana. Istnieje ponadto skomplikowana sieć korespondencji pomiędzy rzeczą i człowiekiem, sprawiająca między innymi, że własności rzeczy nie mogą być rozpatrywane bez odniesienia do jej ludzkiego właściciela. Chrześcijaństwo zachowało wiele elementów myślenia pierwotnego, np. w kulcie relikwii, natomiast w ogólnym planie przyniosło, zwłaszcza początkowo, pogardę

sza - wyrażana w łacińskiej maksymie de individuis nulla scientia - zdecydowała również o tym, że historiografia, skupiona na wydarzeniach jednorazowych, niepowtarzalnych, bardzo długo nie była traktowana w tradycji zachodniej jako nauka.

Por. K. Pomian, Kolekcjonerstwo i filozofia. Narodziny nowożytnego muzeum, [w:] K. Pomian, Drogi kultury europejskiej. Trzy studia, Warszawa 1996, s. 113.

$8 \quad$ P. Cabanne, Wielcy kolekcjonerzy, tłum. F. Buhl, Kraków 1978, s. 22n. 
dla świata materialnego (contemptus mundi) i ciała. Rzeczy materialne, zarówno wytwory ludzkie (artefacta), jak i wytwory przyrody (naturalia), postrzegano jako znaki wyższej rzeczywistości i rozpatrywano symbolicznie. W życiu codziennym zbawieniu miał służyć ascetyzm i wyrzeczenie się przywiązania do doczesności. Epoką, która dowartościowała doczesność i materialność, uznała wytwórczość za signum człowieczeństwa i widomy dowód ludzkiej wspaniałości oraz zwróciła uwagę na rolę pięknego otoczenia w ludzkim życiu codziennym, był renesans. Renesans to także czas hedonizmu, hedonizmu wyrafinowanego, któremu służyć miało cenne i zróżnicowane wyposażenie wnętrz. Z tego czasu wywodzi się idea pracowni uczonego, idea włoskiego studiolo, reprezentowanego np. przez pracownię księcia Federica da Montefeltro (1422-1482) w jego pałacu w Urbino. Pomieszczenie to miało nie tylko być funkcjonalne, ale też spełniać najwyższe wymogi ebenisty oraz mieścić inspirujące obrazy $\mathrm{i}$ inne przedmioty sycące smak przebywającej w nim osoby ${ }^{9}$. Ważne idee wpływające na zmianę w postrzeganiu i wartościowaniu sfery doczesnej przyniosła też w tym czasie religia protestancka. Za jej sprawą dokonało się dowartościowanie zwyczajnego życia ${ }^{10}$, które odrzuciło ideę ścisłej hierarchii miejsc, rzeczy, ludzi i zajęć na rzecz panteizującego przekonania, że Boga może czcić każdy i wszędzie, nie potrzebując do tego pośredników i mogąc się uświęcić, traktując jako powołanie (niem. Beruf) każdy zawód, który przypadł mu w życiowym udziale. Protestantyzm dokonał nieznanej dotąd na Zachodzie sakralizacji przestrzeni domu i stołu. Oto dom stał się małą świątynią, a stół - przy którym ojciec czyta Biblię przed posiłkiem, a następnie kroi chleb - ołtarzem ${ }^{11}$. Współcześnie te postawy

9 Na temat pracowni uczonych i geniuszy por. M. Listri, Le Dimore del Genio, Milano 1996. Autor omawia i prezentuje m.in. pracownie J. W. Goethego, G. Moreau, G. D’Annunzio, G. Pucciniego i M. Praza. We wszystkich tych pracowniach mieściły się starannie wybrane rzeczy (obrazy, rzeźby, meble, ceramika, naturalia), których piękno miało podnosić nastrój przebywających we wnętrzach osób.

10 Jest to termin (ang. affirmation of ordinary life) wprowadzony przez Ch. Taylora w jego studiach nad dziejami zachodniego indywidualizmu i podmiotowości. Por. np. Ch. Taylor, Secular age, Harvard 2009.

11 Wątek ten podejmuje Stefan Symotiuk w art. „Martwa natura” jako traktat filozoficzny, „Sztuka i Filozofia” (1992), nr 5, s. 155-169. „[...] stoły, na których przedstawia się przedmio- 
zanikły, mylilibyśmy się jednak, sądząc, iż dla nas „rzecz jest tylko rzeczą” (Alberto Moravia). Hartmut Böhme pokazał w swym przenikliwym studium, jak dalece, po oświeceniowym odczarowaniu, rzeczy wciąż rozciągają nad nami swą moc i są fetyszyzowane ${ }^{12}$.

\section{Przyjemność zbierania}

Przyjemność obcowania z rzeczami ma wiele aspektów. Na początek przywołajmy przykład. Oto Piero de’Medici, należący do słynnej możnowładczej rodziny zbieraczy, której kolekcja dała podwaliny Galerii Uffizi we Florencji. Czytamy o nim: „Piero de’Medici kazał się często nieść na krześle do swego studia, gdzie jednego dnia oglądał uważnie księgi o złotych grzbietach, podziwiał kosztowne przedmioty, rzeźbione na różne możliwe sposoby: znajdował przyjemność w ich oglądaniu i snuł rozważania na temat ich zalet [artystycznych]; innego znów dnia oglądał z uwagą wazy ze złota, srebra i różnych kruszców oraz podziwiał kunszt ich twórców; kiedy indziej znów zwiedzał przedmioty pochodzące $\mathrm{z}$ różnych stron świata oraz broń różnego typu"13. Dalej dowiadujemy się, że Piero de’Medici posiadał ogromną liczbę rzeczy: było ich tak wiele, że na sam ich obchód i uważne ujrzenie wszystkich potrzebowałby około miesiąca. W cytowanym fragmencie uderza moment kontemplacji jako zasadniczego stosunku właściciela do swych zbiorów, w domyśle zaś pozostaje radość z faktu posiadania tych rzeczy. Zwróćmy teraz uwagę na

ty codziennego użytku, nie są w martwych naturach czymś przypadkowym. To domowe ołtarzyki, na których przedstawia się te wszystkie ucieleśnienia boskości, które należy czcić i szanować. Owe kwiaty we flakonach, owoce w koszach, płyny w naczyniach nabierają zatem charakteru sakralnego: w nich - w martwej materii jest boskość, którą należy czcić. Martwe natury stają się rywalkami krucyfiksów. Jest w nich nawet odpowiednia dostojność, sztywność, uroczystość, ceremonialność. Kwiaty unoszą swe kielichy jak puchary ofiarne, a chleb i wino mają sens symboliczny" (tamże, s. 168). Na temat filozoficznego i moralistycznego wymiaru martwych natur por. też Z. Mikołejko, Mała Vanitas (z kręgu Philippéa de Champaigne), [w:] Z. Mikołejko, Śmierć i tekst. Sytuacja ostateczna w perspektywie słowa, Gdańsk 2001, s. 75n.

${ }_{12}$ Por. H. Böhme, Fetyszyzm i kultura. Inna teoria nowoczesności, tłum. M. Falkowski, Warszawa 2012.

13 A. Filarete, Trattato di Architettura, II, C: 186v, cyt. za: Z. Waźbiński, Muzeum i zbiory artystyczne epoki nowożytnej. Wiek XV i XVI, Toruń 2006, s. 60n. 
doznania Rudolfa II Habsburga (1552-1612), „króla kolekcjonerów”, zwanego tak ze względu na ogrom, różnorodność i cenność jego zbiorów. Szacuje się, że Rudolf II wydawał na zakupy obrazów i innych przedmiotów, w tym relikwii, naturaliów i osobliwości, kwoty równoważne wydatkom na wojnę, a o rozmachu jego przedsięwzięć świadczy też liczba niemal czterdziestu malarzy i rzeźbiarzy, których zatrudniał w tym samym czasie. W wypadku cesarza obcowanie ze sztuką pełniło przede wszystkim rolę terapeutyczną: „W środku nocy, by rozwiać koszmary, udaje się do Gabinetu Cudów, przygląda się szlachetnym kamieniom, słynnym czeskim kryształom, kartkuje inkunabuły, podziwia klejnoty, kielichy z pozłacanego srebra i agatu, głaszcze posążki, opiera rozpalone czoło o ich marmurowe kolana, przykłada do nich usta - i zapomina o otaczającym świecie przemocy i krwi. Chciałby, aby cały świat był świątynią poświęconą nauce i sztuce. Dopóki rządzi, może przynajmniej oszczędzić potworności wojny swym artystom i uczonym: składa u nich zamówienia, a z Pragi tworzy prawdziwy Eden, w którym mogą pracować w spokoju" ${ }^{14}$. Kolekcja Rudolfa miała ambicje poznawczo-naukowe i była uzupełniana tak, aby stworzyć wielką encyklopedię, sumę wiedzy o świecie i pięknie. Preferował dzieła wzbudzające natychmiastowy zachwyt, niewymagające czasu, aby oddziałać mocą swego piękna i które przez to potrafily uspokajać od pierwszego z nimi kontaktu. Obrazu wielkiego zbieracza dopełnia motyw zazdrości o rzeczy: Rudolf II ukrywał niektóre cenne przedmioty przed innymi, posuwając się aż do ich zamurowywania i zakopywania. Zazdrość tego rodzaju jest nierzadka u kolekcjonerów, choć w przypadku cesarza osiągnęła skrajne natężenie.

Zauważmy, że rzecz może cieszyć każdy z ludzkich zmysłów. Wzrok syci się formą, faktura rzeczy cieszy zmysł dotyku, każda rzecz pachnie. Niektóre dawne przedmioty - instrumenty muzyczne, zegary - mogą brzmieć. Najmniejszą rolę w radowaniu się kolekcjonerską rzeczą ma

14 J. Dauxois, Cesarz alchemików Rudolf II Habsburg, tłum. R. Niziołek, Kraków 1997, s. 185. Autorka sugeruje też, że Rudolf traktował swe rzeczy jako coś, na czym może polegać, coś, co nigdy go nie zawiodło i nie oszukało - w odróżnieniu od ludzi. Idea „wierności rzeczy” względem dbającego o nie kolekcjonera-właściciela jest toposem przewijającym się w dziejach namysłu nad kolekcjonerstwem. 
zmysł smaku, bo kosztowanie rzeczy - możliwe w odniesieniu do pewnych przedmiotów - oznaczałoby ich ubytek. Istnieją jednak zbieracze długo leżakowanych lub rzadkich win, którzy w końcu spożywają alkohol ze swoich zbiorów.

Zbieranie przynosi nie tylko przyjemności zmysłowe, lecz także intelektualne. Specjalną przyjemnością dla zbieraczy-kolekcjonerów jest doznanie skompletowania serii rzeczy, którą gromadzili. Zakup ostatniej rzeczy z danej serii stanowi jej „zamknięcie” i staje się przez to momentem triumfu. Z faktem tym łączy się poczucie zapanowania nad rzeczywistością, podporządkowania jej sobie. Kolekcjoner jest tu niczym pan feudalny, który posiada cenne i rzadkie dobra, strzeże ich i stale powiększa obszar posiadania.

\section{Wartość tego, co dawne, i inne źródła przyjemności}

Swoistą przyjemność intelektualną daje obcowanie z rzeczami, które cechuje dawność. Jakość ta emanuje z rzeczy, jest dana w wielu jej jakościach: w spolerowanym drewnie mebli, we wklęsłym druku książek, w przetarciach na powierzchniach ceramiki lub w odłupach farby na malowanych zabytkach techniki, w patynie na powierzchniach sreber i frontach mebli, w miejscach konserwacji starych kilimów. Doznanie dawności jest uchwyceniem w wyobraźni przestrzeni czasu i mnogości zdarzeń, jakie upłynęły od powstania rzeczy do chwili obecnej. Doznanie dawności rzeczy niesie też wyobrażenie o „losach rzeczy”, czyli o jej minionych właścicielach, miejscach, w których przebywała, oraz o zdarzeniach, których była milczącym świadkiem. Alois Riegl wprowadził w tym kontekście pojęcie „wartość dawności” (Alterswert) sugerujące swoistą emocjonalność związaną z rzeczami-pomnikami, a polegającą na tym, że trwająca pomimo upływu czasu rzecz jest dowodem „wygranej” człowieka w prastarym konflikcie między materialnymi dziełami człowieka i niszczącą siłą natury ${ }^{15}$.

15 A. Riegl, Nowoczesny kult zabytków. Jego istota i powstanie, tłum. R. Kasperowicz, [w:] Alois Riegl, Georg Dehio i kult zabytków, tłum. i wstęp R. Kasperowicz, Warszawa 2002, 
Zbierane rzeczy stanowią znaki pamięci, monumenta. Niemieckie słowo Denkmal - będące kategorią we wpływowej koncepcji muzeologicznej Riegla - oznacza właśnie „znak pamięci”, „pamiątkę”, „pomnik”, a przez polskich tłumaczy oddawane bywa często jako „zabytek”; słowo to jest przekładem starogreckiego mnemosynon („pomagający pamięci”). Zbierający rzeczy wspomaga własną pamięć, a nawet poszerza jej obszar. Gromadzone rzeczy pozwalają mu - w zależności od tego, co reprezentują - przywoływać w umyśle nie tylko historię osobistą, a dalej rodzinną, lecz także dzieje ogólnoludzkie. Tego zaś rodzaju ogląd uobecnionej przez rzeczy przeszłości stanowi dużą przyjemność intelektualną ${ }^{16}$.

Jedną z większych przyjemności, które ściśle wiążą się z kolekcjonowaniem rzeczy, jest przyjemność bycia znawcą, koneserem (fr. connoisseur). Jest to przyjemność, która syci ludzką dumę i chęć wyróżnienia się. Bycie znawcą rzeczy nigdy nie jest wrodzone. Smak jest wprawdzie w znacznym stopniu wrodzony, ale dystynktywne znawstwo zawsze pozostaje okupione latami obcowania z rzeczami, latami oglądu, erudycji i rozmów. O tym, jak wiele potrzeba tu czasu, przypominał często malarz, plakacista i wybitny kolekcjoner Franciszek Starowieyski, twierdząc, że wykształcenie dobrego antykwariusza wymaga co najmniej dwudziestu lat ${ }^{17}$. Antykwariusz nie jest bowiem specjalistą, lecz wszechstronnym uczonym - znawcą wielu dziedzin przedmiotowych.

Kolejna przyjemność zbieraczy to przyjemność posiadania rzeczy unikalnych, osobliwych. Im bardziej rzecz jest unikalna, tym przyjemność większa, gdyż takie posiadanie wyróżnia. Unikat jest rzeczą pojedynczą,

s. 27-70. Por. też J. Krawczyk, Meble jako przedmioty użytkowe i zabytki. U podstaw problematyki konserwatorskiej mebli zabytkowych, Toruń 2006, gdzie autor interesująco wykorzystuje koncepcję Riegla do interpretacji dawnych mebli jako monumenta.

16 Można tu mówić o trzech modusach oglądu dziejów: monumentalnym (nastawionym na to, co wielkie, wybijające się), antykwarycznym (skupionym na pełnym czci [pietas] obcowaniu z pamiątkami małych ojczyzn i rodzin) oraz krytycznym (dla którego dawne rzeczy stanowią świadectwa pro i contra formułowanych tez). Te trzy modusy oglądu dziejów i pisania historii wprowadził Nietzsche w rozprawie Pożyteczność i szkodliwość historii dla życia, [w:] F. Nietzsche, Niewczesne rozważania, tłum. L. Staff, posłowie D. Misztal, Wrocław 2003, s. 61-122.

17 Por. I. Górnicka-Zdziech, Przewodnik zacnego kolekcjonera wedtug Franciszka Starowieyskiego, Warszawa 2008. 
idiomatyczną, nieseryjną. Zdobycie zaś rzeczy unikalnej przynosi jeszcze przyjemną satysfakcję z tego, że zrealizowaliśmy plan, zapanowaliśmy nad światem, dopięliśmy swego. Rodzi to w zbieraczu poczucie dumy.

Zbieranie bywa także rodzajem budowania azylu, ucieczki od świata. Daje przyjemność oderwania od świata, przyjemność eskapizmu. Rzecz jasna idzie o oderwanie od tego, co w świecie uznawane jest za brzydkie, brudne, nieszlachetne, złe - co ma zatem ujemną wartość estetyczną i moralną - i pogrążenie się w pięknie. Niekiedy uwielbienie dla piękna rzeczy może się wzmagać wskutek dostrzeżenia szpetoty własnej, jak to było w przypadku Rudolfa II Habsburga, który w podeszłym wieku brzydł fizycznie na skutek chorób ${ }^{18}$. W tym kontekście dochodzi do głosu - wykorzystywana we współczesnej arteterapii - terapeutyczna funkcja piękna i pięknych rzeczy. Już Platon zauważył, że widok piękna podnosi nastrój - w przeciwieństwie do widoku brzydoty, który ma moc obniżania nastroju.

Trywialną, choć nierzadko spotykaną przyjemnością kolekcjonerów jest przyjemność posiadania rzeczy cennych w znaczeniu pieniężnym, rzeczy rynkowo zbywalnych. Rzeczy takie, np. dzieła sztuki lub numizmaty, stanowią lokatę środków, a przy tym nie są „martwe”, lecz - będąc w jego stałej dyspozycji - cieszą zbieracza. Posiadanie rzeczy o sporej wartości rynkowej naraża jednak kolekcjonera na kradzież i tym samym mąci jego szczęście.

Zbieranie i kolekcjonowanie rzeczy oznacza najczęściej także ich posiadanie. Dlatego wiele szczęścia może ono zapewnić ludziom o posesywnym typie osobowości, któremu radość przynosi przede wszystkim posiadanie na własność ${ }^{19}$. Typ posesywny ponadto obciążony jest chciwością, ową grecką pleonexia, która w tym akurat wypadku ma następstwa korzystne dla społeczeństwa. Kolekcjoner zbiera cenne rzeczy, które bez jego troski i zapobiegliwości mogłyby zniszczeć lub zostać sprzedane poza granice danego kraju. Kolekcjoner ocala rzeczy nie tylko dla siebie, ale nolens volens także dla innych, najpierw sobie współczesnych, a dalej

18 Por. J. Dauxois, Cesarz alchemików Rudolf II Habsburg, dz. cyt., s. 188.

19 W. Tatarkiewicz, O szczęściu, Warszawa 1960, s. 43n. 
także potomnych. Nierzadko jest fundatorem muzeum. Kolekcjonerstwo ma zatem w tym przypadku swój aspekt patriotyczny.

Wspomnijmy jeszcze o pomniejszych przyjemnościach zbieraczy. Wiążą się z emocjami poszukiwań, antycypowaniem zakupu, momentem wejścia w posiadanie rzeczy, a następnie z jej pokazywaniem, wypożyczaniem na własnych warunkach, $\mathrm{z}$ doświadczaniem podziwu ze strony innych koneserów. Być może dopiero cudza zazdrość może nieco zmącić radość posiadania przez nas jakiejś rzeczy.

\section{Zakończenie}

James Clifford argumentował z perspektywy antropologa, że przyjemność zbierania i kolekcjonowania rzeczy jako własności jest powiązana $\mathrm{z}$ zachodnim indywidualizmem i ideą poszerzania Ja przez należące do nas dobra. Zachód przyjął koncepcję tożsamości jako „rodzaju bogactwa” ${ }^{20}$. Należy jednak zauważyć, że także w kulturze zachodniej istnieje wielu ludzi, którzy pozostają niewrażliwi na przyjemności, jakich mogą dostarczyć rzeczy - cechuje ich w tym względzie osobliwa ahedonia. Jako ahedoniści ludzie tacy są wolni od pasji zbieraczej. Bywają też wolni od zainteresowania przeszłością w ogóle. Możliwa jest względem rzeczy także postawa pośrednia: można je mianowicie oglądać i podziwiać, lecz nie zbierać. Taka wolność od pragnienia posiadania jest uczuciem wzniosłym w sensie Kantowskim i była proponowana przez Arthura Schopenhauera jako warunek wyzwolenia się od cierpień powodowanych przez nigdy nienasyconą wolę.

Należy jednak dostrzec, że pomimo wszystkich niedogodności, trudów i kosztów, których wymaga zbieranie rzeczy - a po części zaś właśnie dzięki nim - kolekcjonowanie rzeczy to jedno z najszlachetniejszych ludzkich zajęć i jedna z najszlachetniejszych przyjemności. Kolekcjonowanie jest kształcące w wielu aspektach, wyrabia smak estetyczny, działa

20 Por. J. Clifford, O kolekcjonowaniu sztuki i kultury, tłum. J. Iracka, [w:] J. Clifford, Kłopoty z kulturą. Dwudziestowieczna etnografia, literatura i sztuka, tłum. E. Dżurak i in., Warszawa 2000, s. 236. 
terapeutycznie, budzi miłość do piękna. Rozbudza ciekawość i utrzymuje umysł w stanie ciągłego pobudzenia poznawczego. Wyrabia ponadto w oddających mu się ludziach specjalne cnoty, a mianowicie dokładność, dbałość, troskę, pietyzm, cierpliwość i pracowitość. O zbieraniu i kolekcjonowaniu można powiedzieć to, co jest prawdą w odniesieniu do różnych odmian historyzmu - że są one wyrazem wielkiej miłości do widzialnego świata.

Aspekt społeczny i socjotwórczy kolekcjonowania rzeczy nie jest oczywisty. Wolno sądzić, że wielu, jeśli nie większość, kolekcjonerów to samotnicy. Ludzie ci nie szukają kontaktu pozaprofesjonalnego z podobnymi sobie. Jest natomiast jasne, że budując kolekcje - czyli gromadząc rzeczy będące semioforami (niosącymi znaczenia) i znakami pamięci - oddają ogromne przysługi społeczeństwu, w którym żyją, oraz potomności. Dlatego właśnie kolekcjonerzy są soczewkami swoich epok i „centralnymi postaciami kultury"21.

\section{Bibliografia}

Böhme H., Fetyszyzm i kultura. Inna teoria nowoczesności, tłum. M. Falkowski, Warszawa 2012.

Cabanne P., Wielcy kolekcjonerzy, tłum. F. Buhl, Kraków 1978.

Clifford J., O kolekcjonowaniu sztuki i kultury, tłum. J. Iracka, [w:] J. Clifford, Kłopoty z kultura. Dwudziestowieczna etnografia, literatura i sztuka, tłum. E. Dżurak i in., Warszawa 2000, s. 231-267.

Dauxois J., Cesarz alchemików Rudolf II Habsburg, tłum. R. Niziołek, Kraków1997.

Drüe E., Ekscentryczność jako otwarty wyraz duchowości, [w:] Duch i dusza, red. P. Dybel, Warszawa 2001, s. 100-111.

Górnicka-Zdziech I., Przewodnik zacnego kolekcjonera według Franciszka Starowieyskiego, Warszawa 2008.

Listri M., Le Dimore del Genio, Milano 1996.

21 K. Pomian, Zbieracze i osobliwości. Paryż-Wenecja XVI-XVIII wiek, tłum. A. Pieńkos, Gdańsk 2012. 
Nietzsche F., Niewczesne rozważania, tłum. L. Staff, posł. D. Misztal, Wrocław 2003.

Norman D. A., Wzornictwo i emocje, tłum. D. Skalska-Stefańska, Warszawa 2015.

Pomian K., Jak uprawiać historię kultury, „Przegląd Historyczny” (1995), nr 1, s. 1-13.

Pomian K., Kolekcjonerstwo i filozofia. Narodziny nowożytnego muzeum, [w:] K. Pomian, Drogi kultury europejskiej. Trzy studia, Warszawa 1996, s. 109-171.

Pomian K., Zbieracze i osobliwości. Paryż-Wenecja XVI-XVIII wiek, tłum. A. Pieńkos, Gdańsk 2012.

Riegl A., Nowoczesny kult zabytków. Jego istota i powstanie, tłum. R. Kasperowicz, [w:] Alois

Riegl, Georg Dehio i kult zabytków, tłum. i wstęp R. Kasperowicz, Warszawa 2002, s. $27-70$.

Sommer M., Zbieranie. Próba filozoficznego ujęcia, tłum. J. Merecki, Warszawa 2003.

Symotiuk S., „Martwa natura” jako traktat filozoficzny, „Sztuka i Filozofia” (1992), nr 5, s. $155-169$.

Swieżawski S., Zbieżności metafizyki realistycznej i historiografii, [w:] Szkice filozoficzne.

Romanowi Ingardenowi $w$ darze, Warszawa-Kraków 1964, s. 267-287.

Taylor Ch., Secular age, Harvard 2009.

Waźbiński Z., Muzeum i zbiory artystyczne epoki nowożytnej. Wiek XV i XVI, Toruń 2006. 